\title{
Study of Cutaneous Manifestations in End Stage Kidney Disease Undergoing Hemodialysis
}

\author{
Maskey $A^{1}$, Kumar $A^{2}$, Shrestha $R^{3}$ \\ ${ }^{1}$ Associate professor, Department of Medicine, ${ }^{2}$ Associate professor, Department of Dermatology, ${ }^{3}$ Resident, Department \\ of Medicine, Manipal Teaching Hospital, Pokhara, Nepal
}

\begin{abstract}
Introduction: The prevalence of cutaneous manifestations in hemodialysis patients is increasing.

Objectives: The aim of this study was to determine the prevalence and pattern of various cutaneous manifestations in patients undergoing maintenance hemodialysis.

Material and Methods: A hospital based cross sectional study was conducted in patient undergoing maintenance hemodialysis at least for three months in dialysis unit of Manipal Teaching Hospital Pokhara, Nepal during the period from August 2018 to January 2019. A demographic questionnaire and a checklist about cutaneous disorders were used for data collection. Patients with cholestatic liver disease or acute hepatitis, active infection, active malignancy, patient with acute kidney injury, patient undergoing peritoneal dialysis and renal transplant recipient were excluded from study.

Results: Total 80 patients undergoing maintenance hemodialysis were included. Among them, 52 (65\%) patients were male. The mean age of study population was $51.95 \pm 14.96$ years. The mean duration of dialysis was $40.28 \pm 11.09$ months. The most common cause of end stage kidney disease was diabetic nephropathy. The most common cutaneous manifestations were pigmentation (82.5\%), nail changes (75\%), xerosis $(70 \%)$ and pruritis $(50 \%)$.

Conclusions: The results of this study revealed that patients on hemodialysis were associated with multiple cutaneous symptoms, the most prevalent of which were pigmentation and nail disorders. Therefore, early diagnosis of these problems is a major step in improving the quality of life in these patients.
\end{abstract}

Key words: Diabetic Nephropathies; Kidney Failure, Chronic; Pruritus; Renal Dialysis

\section{Introduction}

A wide array of skin diseases occurs in patients with chronic kidney disease. These diseases are seldom related to the underlying renal diseases but are more frequently directly or indirectly associated with 'uremia' in its broadest sense. With an almost $100 \%$ prevalence in dialysis populations, skin disorders are frequently the subject of patients' complaints. ${ }^{1}$ They can significantly affect patient's quality of life with negative impact in their mental and physical health and early detection and treatment can dramatically alter their course with improvement of quality of life..$^{2,3}$

Financial disclosure: None.

Conflict of interest to disclosure: None declared.

\section{Address of Correspondence}

Dr. Abhishek Maskey

Associate Professor

Department of Medicine, Manipal teaching hospital,

Pokhara, Nepal.

E-mail: maskey21@hotmail.com
A fair knowledge of the dermatological conditions that can arise in the setting of kidney disease is, therefore, very useful to practicing nephrologists.

In developed countries, increased availability of improved dialysis therapy has led to a decrease in metabolic and cutaneous complications. ${ }^{4}$ However,

Submitted: $15^{\text {th }}$ December 2019

Accepted: $15^{\text {th }}$ February 2020

Published: $7^{\text {th }}$ October 2020

How to cite this article

Maskey A, Kumar A, Shrestha R. Study of cutaneous manifestations in end stage kidney disease undergoing hemodialysis. Nepal Journal of Dermatology Venereology and Leprology 2020;18(1):37-43. https://doi.org/10.3126/njdvl. v18i1.29568.

\section{(c) (i)}

Licensed under CC BY 4.0 International License which permits use, distribution and reproduction in any medium, provided the original work is properly cited. 
in Nepal inadequate and unaffordable facilities for dialysis and renal transplantation leave most patients untreated or undertreated, hence cutaneous complications are more common in dialysis patients.

In addition, Nepalese population is subjected to the harmful effects of its tropical climate, with high incidence of infection affecting the cutaneous outcome adversely. ${ }^{4}$

There is a paucity of studies assessing cutaneous anomalies in end stage kidney disease (ESKD) patients undergoing hemodialysis in Western region of Nepal. Therefore, the present study is undertaken to study prevalence and pattern of cutaneous manifestations in maintenance hemodialysis patients in hospital setting.

\section{Material and Methods}

A hospital based cross sectional study was done in patient undergoing maintenance hemodialysis at least for three months of either sex, aged 18 years and above, attending dialysis unit of Manipal Teaching Hospital Pokhara, Nepal during the period from August 2018 to January 2019. The study was approved by Institutional Review Committee of Manipal College of Medical Sciences.

Patients with cholestatic liver disease or acute hepatitis, active infection, active malignancy, patient with acute kidney injury, patient undergoing peritoneal dialysis and renal transplant recipient were excluded from study.

A performa was used for data collection. Patients demography including name, age, sex, occupation and address, duration of maintenance hemodialysis, any dermatological complaints at present or past and history of drug hypersensitivity was recorded. Blood investigations like hemoglobin, blood urea and serum creatinine, hepatitis serology (hepatitis B surface antigen and hepatitis C antibody), serum calcium, phosphorus was done. Patients were thoroughly examined and skin, mucous membrane, hair and nail changes was noted. Scraping for fungus and pus for culture and sensitivity was done whenever necessary.

A comprehensive and systemic dermatologic examination including skin appendages and confirmation of presenting lesion was performed by qualified senior dermatologist.

All the data was entered in Microsoft Excel spread sheet. Analysis was performed using statistical software (IBM SPSS statistics 20, SPSS Inc. an IBM Corp, NY USA). Continuous data was described as arithmetic mean and standard deviation and categorical data as actual numbers and percentages.

\section{Results}

Total 80 patients undergoing maintenance hemodialysis were included in our study. Among them, 52 (65\%) patients were male. The mean age of study population was $51.95 \pm 14.96$ years. The mean duration of dialysis was $40.28 \pm 11.09$ months. Diabetes was the most common cause of ESKD in these patients $(n=50)$, followed by chronic glomerulonephritis $(n=9)$, hypertension ( $n=9)$, obstructive nephropathy $(n=1)$ and others include polycystic kidney $(n=6)$, malignancy $(n=4)$ and unknown cause $(n=3)$ cases. Other baseline characteristics in these patients are outlined in table-1.

One or more cutaneous manifestations were present in $92 \%$ of patients. Pigmentation $(82.5 \%)$, nail changes (75\%), xerosis $(70 \%)$ and pruritis $(50 \%)$ were the most common observed findings.

Diffuse pigmentation was the most common findings seen in 66 (82.5\%) patients. Out of these 66 patients, pigmentation was generalised in $60 \%$, localised in $25 \%$ and patchy in $15 \%$. Face and extremities were commonly involved. Other pigmentary changes observed are listed in table-2.

The second most frequent finding was nail changes. Longitudinal striations of nail were the most common nail changes seen in $60(75 \%)$ patients. Other changes included pallor in 33(41.3\%), nail pitting in $27(33.8 \%)$, absent lunula in $24(30 \%)$, half and half nail in $10(12.5 \%)$ and leukonychia in $2(2.5 \%)$ patients shown in table-3.

Xerosis was found in 56 (70\%) patients. Among these 56 patients, xerosis was generalised in 40 (71.42\%), localised in 10 (17.85\%), and patchy in 6 (10.71\%) patents. Xerosis was more common in diabetic patients. Pruritus was seen in 40 (50\%) patients. It was generalised in 28 (70\%), localised in 10 (25\%) and patchy in remaining $2(5 \%)$ patients depicted in table4.

In oral mucosal changes, coated tongue was seen in $34(42.5 \%)$ patients and $33(41.25 \%)$ patients had diffuse alopecia. Twenty-five (31.25\%) patients in this study had cutaneous infections; 12 (15\%) were viral, 9 (11.5\%) were bacterial, 4 (5\%) were fungal shown in table-5. 
Table 1: Baseline characteristics and etiology of ESKD of study population

\begin{tabular}{|l|c|}
\hline Mean age (years) & $\mathbf{5 1 . 9 5 \pm 1 4 . 9 6}$ \\
\hline Gender (Male vs Female) & 52 vs 28 \\
\hline Haemoglobin (gm/dl) & $8.50 \pm 1.82$ \\
\hline Blood urea (mg/dl) & $125.77 \pm 1.82$ \\
\hline Serum Creatinine (mg/dl) & $10.07 \pm 3.09$ \\
\hline Duration of dialysis (months) & $40.28 \pm 11.09$ \\
\hline Etiology of ESKD & \\
\hline Diabetic nephropathy (\%) & $50(62.5)$ \\
\hline Chronic glomerulonephritis (\%) & $9(11.25)$ \\
\hline Hypertensive nephropathy (\%) & $7(8.75)$ \\
\hline Obstructive nephropathy(\%) & $1(1.25)$ \\
\hline Others (\%) & $13(16.25)$ \\
\hline
\end{tabular}

Table 2: Skin and pigmentary changes in study population

\begin{tabular}{|c|c|c|c|c|c|c|}
\hline Pigmentary changes & $\begin{array}{c}\text { Total } \\
n=80 \\
(100 \%)\end{array}$ & $\begin{array}{c}\text { DN } \\
n=50 \\
(62.5 \%)\end{array}$ & $\begin{array}{c}\text { CGN } \\
n=9 \\
(11.3 \%)\end{array}$ & $\begin{array}{c}\text { HTN } \\
n=7 \\
(8.8 \%)\end{array}$ & $\begin{array}{l}\text { O. Nephropathy } \\
\begin{array}{c}n=1 \\
(1.3 \%)\end{array}\end{array}$ & $\begin{array}{c}\text { Others } \\
n=13 \\
(16.25 \%)\end{array}$ \\
\hline Diffuse brown pigmentation & $66(82.5 \%)$ & 46 & 9 & 5 & 0 & 6 \\
\hline Skin pallor & $9(11.3 \%)$ & 5 & 1 & 1 & 0 & 2 \\
\hline Yellowish discoloration & $7(8.8 \%)$ & 3 & 0 & 0 & 1 & 3 \\
\hline $\begin{array}{l}\text { Brownish to slate gray } \\
\text { pigmentation }\end{array}$ & $5(6.3 \%)$ & 4 & 0 & 1 & 0 & 0 \\
\hline \multicolumn{7}{|l|}{ Skin infections } \\
\hline Herpes Zoster & $10(12.5 \%)$ & 8 & 0 & 2 & 0 & 0 \\
\hline Tinea cruris & $4(5 \%)$ & 4 & 0 & 0 & 0 & 0 \\
\hline Tinea corporis & $3(3.8 \%)$ & 2 & 0 & 1 & 0 & 0 \\
\hline Tinea pedis & $2(2.5 \%)$ & 1 & 0 & 1 & 0 & 0 \\
\hline Diabetic foot ulcer & $2(2.6 \%)$ & 0 & 0 & 2 & 0 & 0 \\
\hline Wart & $2(2.5 \%)$ & 2 & 0 & 0 & 0 & 0 \\
\hline Furuncle & $2(2.6 \%)$ & 2 & 0 & 0 & 0 & 0 \\
\hline
\end{tabular}

DN: Diabetic nephropathy; CGN: Chronic glomerulonephritis; HTN: hypertension; Uropathy: obstructive uropathy

Table 3: Nail changes in study population.

\begin{tabular}{|c|c|c|c|c|c|c|}
\hline Nail changes & $\begin{array}{c}\text { Total } \\
n=80 \\
(100 \%)\end{array}$ & $\begin{array}{c}\text { DN } \\
n=50 \\
(62.5 \%)\end{array}$ & $\begin{array}{c}\text { CGN } \\
n=9 \\
(11.3 \%)\end{array}$ & $\begin{array}{c}\text { HTN } \\
n=7 \\
(8.8 \%)\end{array}$ & $\begin{array}{c}\text { O. Nephropathy } \\
\qquad \begin{array}{c}n=1 \\
(1.3 \%)\end{array}\end{array}$ & $\begin{array}{c}\text { Others } \\
n=13 \\
(16.25 \%)\end{array}$ \\
\hline $\begin{array}{l}\text { Longitudinal } \\
\text { striations }\end{array}$ & $60(75 \%)$ & 41 & 7 & 6 & 1 & 5 \\
\hline Pallor & $33(41.3 \%)$ & 18 & 4 & 2 & 0 & 9 \\
\hline Pitting & $27(33.8 \%)$ & 14 & 2 & 3 & 1 & 7 \\
\hline Absent lunula & $24(30 \%)$ & 19 & 1 & 2 & 0 & 2 \\
\hline Half and half nail & $10(12.5 \%)$ & 8 & 0 & 1 & 0 & 1 \\
\hline $\begin{array}{c}\text { Subungal } \\
\text { hyperkeratosis }\end{array}$ & $4(5 \%)$ & 2 & 1 & 0 & 0 & 1 \\
\hline Leuconychia & $2(2.5 \%)$ & 2 & 0 & 0 & 0 & 0 \\
\hline
\end{tabular}

DN: Diabetic nephropathy; CGN: Chronic glomerulonephritis; HTN: hypertension; O.Nephropathy: Obstructive nephropathy 
Table 4: Dermatological changes in study population.

\begin{tabular}{|c|c|c|c|c|c|c|}
\hline $\begin{array}{l}\text { Dermatological } \\
\text { changes }\end{array}$ & $\begin{array}{c}\text { Total } \\
n=80 \\
(100 \%)\end{array}$ & $\begin{array}{c}\text { DN } \\
n=50 \\
(62.5 \%)\end{array}$ & $\begin{array}{c}\text { CGN } \\
n=9 \\
(11.3 \%)\end{array}$ & $\begin{array}{c}\text { HTN } \\
n=7 \\
(8.8 \%)\end{array}$ & $\begin{array}{c}\text { O.Nephropathy } \\
\begin{array}{c}n=1 \\
(1.3 \%)\end{array}\end{array}$ & $\begin{array}{c}\text { Others } \\
n=13 \\
(16.25 \%)\end{array}$ \\
\hline Xerosis & $56(70 \%)$ & 37 & 6 & 4 & 1 & 8 \\
\hline Pruritus & $40(50 \%)$ & 26 & 4 & 3 & 1 & 6 \\
\hline Seborrheic dermatitis & $4(5 \%)$ & 3 & 0 & 0 & 0 & 1 \\
\hline Eczema & $4(5 \%)$ & 2 & 0 & 1 & 0 & 1 \\
\hline Bilateral pedal edema & $3(3.8 \%)$ & 2 & 1 & 0 & 0 & 0 \\
\hline Excoriations & $3(3.8 \%)$ & 1 & 0 & 1 & 1 & 0 \\
\hline Lichen simplex chronicus & $2(2.5 \%)$ & 0 & 0 & 0 & 0 & 2 \\
\hline Acneiform eruptions & $2(2.5 \%)$ & 2 & 0 & 0 & 0 & 0 \\
\hline Prurigo nodularis & $2(2.5 \%)$ & 1 & 0 & 1 & 0 & 0 \\
\hline Ecchymotic patch & $2(2.5 \%)$ & 1 & 1 & 0 & 0 & 0 \\
\hline Multiple papular lesions & $2(2.5 \%)$ & 0 & 1 & 0 & 1 & 0 \\
\hline Lichenified plaque with excoriations & $2(2.5 \%)$ & 0 & 1 & 0 & 1 & 0 \\
\hline $\begin{array}{l}\text { Reticular patterned dry ichthyotic } \\
\text { lesion }\end{array}$ & $2(2.5 \%)$ & 1 & 0 & 0 & 1 & 0 \\
\hline Uric acid tophi/ecchymotic patches & $2(2.5 \%)$ & 1 & 0 & 0 & 1 & 0 \\
\hline Vitiligo & $1(1.3 \%)$ & 1 & 0 & 0 & 0 & 0 \\
\hline Annular eczema & $1(1.3 \%)$ & 1 & 0 & 0 & 0 & 0 \\
\hline Chronic dermatitis & $1(1.3 \%)$ & 0 & 0 & 0 & 0 & 1 \\
\hline Dupyutren's contracture & $1(1.5 \%)$ & 0 & 0 & 0 & 1 & 0 \\
\hline Follicuitis of scalp & $1(1.3 \%)$ & 0 & 0 & 0 & 1 & 0 \\
\hline Skin tag/angioma & $1(1.3 \%)$ & 1 & 0 & 0 & 0 & 0 \\
\hline Stria seen over trunk & $1(1.3 \%)$ & 0 & 0 & 0 & 0 & 1 \\
\hline
\end{tabular}

Table 5: Oral mucosal and hair changes of study population

\begin{tabular}{|c|c|c|c|c|c|c|}
\hline $\begin{array}{l}\text { Oral mucosal } \\
\text { changes }\end{array}$ & $\begin{array}{c}\text { Total } \\
n=80 \\
(100 \%)\end{array}$ & $\begin{array}{c}\text { DN } \\
n=50 \\
(62.5 \%)\end{array}$ & $\begin{array}{c}\text { CGN } \\
n=9 \\
(11.3 \%)\end{array}$ & $\begin{array}{c}\text { HTN } \\
n=7 \\
(8.8 \%)\end{array}$ & $\begin{array}{l}\text { O. Nephropathy } \\
n=1(1.3 \%)\end{array}$ & $\begin{array}{c}\text { Others } \\
n=13 \\
(16.25 \%)\end{array}$ \\
\hline Coated tongue & $34(42.5 \%)$ & 24 & 3 & 4 & 1 & 2 \\
\hline Fissured tongue & $21(26.3 \%)$ & 13 & 2 & 4 & 0 & 2 \\
\hline Xerostomia & $6(7.5 \%)$ & 5 & 1 & 0 & 0 & 0 \\
\hline $\begin{array}{l}\text { Hypertrophic papilla in } 1 / 3 \text { rd of } \\
\text { tongue }\end{array}$ & $4(5 \%)$ & 2 & 0 & 0 & 0 & 2 \\
\hline Pallor & $2(2.5 \%)$ & 2 & 0 & 0 & 0 & 0 \\
\hline Erythematous lesion on tongue & $1(1.3 \%)$ & 1 & 0 & 0 & 0 & 0 \\
\hline Venous lake over tongue, upper lip & $1(1.3 \%)$ & 1 & 0 & 0 & 0 & 0 \\
\hline \multicolumn{7}{|l|}{ Hair changes } \\
\hline Diffuse alopecia & $33(41.25 \%)$ & 22 & 6 & 3 & 1 & 1 \\
\hline Androgenic alopecia & $24(30 \%)$ & 18 & 2 & 4 & 0 & 0 \\
\hline Sparse body hair & $2(2.5 \%)$ & 2 & 0 & 0 & 0 & 0 \\
\hline
\end{tabular}

DN: Diabetic nephropathy; CGN: Chronic glomerulonephritis; HTN: hypertension; O.Nephropathy: Obstructive nephropathy 


\section{Discussion}

Cutaneous manifestations are very common in patients with ESKD. ${ }^{4}$ In our study population $92 \%$ had some form of cutaneous complaints. Nunley et al reported 50-100\% patients with chronic kidney disease have at least one cutaneous manifestation. ${ }^{5}$ Pico et al found prevalence of cutaneous disease in $100 \%$ of patient. ${ }^{6}$ In study conducted by Khanna et al, cutaneous disorders were found in $96 \%$ of patients. ${ }^{4}$ Similarly, study carried out in Nepal by Shrestha et al found $86 \%$ of hemodialysis patients have cutaneous disorder. ${ }^{7}$

Pigmentation (82.5\%), nail changes (75\%), xerosis (70\%) and pruritus (50\%) were most commonly observed findings. These findings are consistent with the findings of other studies by Pico et al, Khanna et al, Amatya et al and Robinson et al. 4,6,8,9

Pigmentation was found in $82.5 \%$ of patient in our study. Similarly, study done in Pakistan by Muhammad et al, found pigmentation in $86 \%$ of hemodialysis patients. ${ }^{10}$ This high prevalence might be probably due to the failure of kidneys and dialysis to excrete beta melanocyte- stimulating hormone and resultant melanin deposition in basal layer as well as in superficial dermis. ${ }^{11}$ Tropical climate and sun exposure may result in increased prevalence of diffuse hyperpigmentation as is evident from predominant involvement of photoexposed areas with sparing of trunk in our study. On contrary to our study, Raiesifar et al and Kolla et al observed pigmentation only in $46 \%$ and $40 \%$ of hemodialysis population respectively in their study. ${ }^{12,13}$

Ungual manifestations occurring in patients with ESKD are polymorphic and diverse. The prevalence of nail changes in patient on hemodialysis has been variable in different studies (52-70\%). ${ }^{14,15}$ Nail changes was the second most common cutaneous disorder in our study. In study done by Ashok et al, showed only $53 \%$ patients had nail disorders. ${ }^{14}$ Aqil et al in their study found $80 \%$ patients had nail disorders. Longitudinal striations were found in $64.2 \%$ patients in their study. ${ }^{15}$ Similarly in this study longitudinal striations were found in $75 \%$ of study population. In our study, absent lunula, was observed in $30 \%$ patients. It may be attributed to anaemia and metabolic abnormalities. ${ }^{16}$ Lindsay's nails (half and half nail) was seen in $12.5 \%$ patients in our study. Contrast to our study, Thomas et al showed $36.36 \%$ patients had half and half nail, the most common nail disorder in their study. ${ }^{17}$

Xerosis was found in $70 \%$ patients in our study. Similar findings were reported in different studies done in hemodialysis population. ${ }^{4,17,18} \mathrm{~A}$ reduction in the size and functional abnormality of eccrine sweat glands, suggesting compromised eccrine secretion leading to epithelial dehydration may contribute to the development of xerosis. ${ }^{19}$ In addition, other factors like poor socioeconomic status of our patients, high dose diuretics, excessive ultrafiltration, greater exposure to dust and detergents and poor use of emollients in general are attributed for the cause of xerosis. Tropical climate with greater sun exposure and resultant chronic dehydration may be contributory. ${ }^{20}$

Pruritus is a common symptom in hemodialysis patients that can cause severe discomfort. It is difficult to treat, as its underlying pathophysiological mechanism is not precisely known. ${ }^{2}$ The prevalence of pruritus varies between $30 \%$ and $64 \%$ in the literature. ${ }^{21,22}$ We found that $50 \%$ of our patients had pruritus, which is comparable to prior reports..$^{4,7,13,23}$ Pruritus was more frequent and severe in diabetics in our study. Dry lustreless skin could have contributed for such a high percentage in our study group. Morton et al showed lower hydration of stratum corneum in uremic patients with pruritus and dry skin promotes sensation of itch by lowering the threshold for itch. ${ }^{24}$

Mucosal disorders like coated tongue and fissured tongue were seen in $42.5 \%$ and $26.3 \%$ respectively of our study patients. Hajheidari et al have reported a prevalence of $24 \%$, with the most common finding being furred tongue (8\%), while Yaghubi et al reported a prevalence of mucosal disorders of $29 \%$, with the most common finding being gingivitis. ${ }^{25,26}$

Cutaneous infection was seen in $31.5 \%$ patient in present study, among them 12 (15\%) were viral, 9 (11.5\%) were bacterial, 4 (5\%) were fungal. In contrast to our study, Udaykumar et al showed higher prevalence of infections like fungal (30\%), bacterial (13\%) and viral (12\%) infections. ${ }^{1}$ Patients with chronic kidney disease have impaired cellular immunity due to a decreased T lymphocyte cell count contributing to high prevalence of infection in these patients. Hair changes were observed with diffuse alopecia in 33 (41.25\%) and androgenic alopecia in 24 (30\%) patient in our study whereas Thomas $A$ et al showed 16 (16.16\%) patients had sparse body hair and 7 (7.07\%) patients had dry lustreless hair. ${ }^{17}$

\section{Conclusion}

Present study found that there is a high prevalence of cutaneous manifestations in hemodialysis patients. Pigmentation, nail disorders, xerosis and pruritus were the most common changes. Recognition and management of some of these cutaneous 
manifestations vastly reduce the morbidity and improve the quality of life. We suggest some prophylactic procedures such as application of moisturizers for prevention of dryness, avoiding sun light for prevention of pigmentation changes, and mouth hygiene for prevention of oral lesions. These measures can help patients on hemodialysis to have better cutaneous and mucosal conditions.

\section{References}

1. Udayakumar $\mathrm{P}$, Balasubramanian $\mathrm{S}$, Ramalingam KS, Chembolli L, Srinivas CR, Mathew A. Cutaneous manifestations in patients with chronic renal failure on hemodialysis. Indian J Dermatol Venereol Leprol 2006;72:119-25. https://doi.org/10.4103/0378-6323.25636

2. Narita I, Alchi B, Omori K, Sato F, Ajiro J, Saga D, et al. Etiology and prognostic significance of uremic pruritus in chronic hemodialysis patients. Kidney Int 2006; 69:1626-32. https://doi.org/10.1038/ sj.ki.5000251

3. Kuypers DRJ. Skin problems in chronic kidney disease. Nature Clinical Practice Nephrology 2009;5:157-70. https://doi.org/10.1038/ ncpneph1040

4. Khanna D, Singal A, Kalra OP. Comparison of cutaneous manifestations in chronic kidney disease with or without dialysis Postgraduate Medical Journal 2010;86:641-7. https://doi. org/10.1136/pgmj.2009.095745

5. Nunley JR. Dermatologic manifestations of renal disease. eMedicine. 2002:550. [Cited $15^{\text {th }}$ November 2019] [Available from: https:// emedicine.medscape.com/article/1094846overview]

6. Pico MR, Lugo-Somolinos A. Cutaneous alterations in patients with chronic renal failure. Int J Dermatol 1992;31:860-3. https://doi. org/10.1111/j.1365-4362.1992.tb03543.x

7. Shrestha $P$, Mathur $M$. Dermatologic manifestations in chronic kidney disease patients on hemodialysis.Nepal Journal of Dermatology, Venereology and Leprology 2014; 12:34-40. https://doi.org/10.3126/njdvl.v12i1.10594

8. Amatya B, Agrawal S, Dhali T, Sharma S, Pandey SS. Pattern of skin and nail changes in chronic renal failure in Nepal. A hospital based study. J Dermatol 2008;35: 140-5. https://doi. org/10.1111/j.1346-8138.2008.00433.x

9. Robinson-BostomL, DiGiovanna JJ. Cutaneous manifestations of end stage renal disease. J Am Acad Dermatol 2000;43:975-90. https://doi. org/10.1067/mjd.2000.110651

10. Anees M, Butt G, Gull S, Nazeer A, Hussain I, Ibrahim M. Factors Affecting Dermatological
Manifestations in Patients with End Stage Renal Disease. J Coll Physicians Surg Pak 2018;28:98102. https://doi.org/10.29271/jcpsp.2018.02.98

11. Smith AG, Shuster S, Comaish JS, Plummer NA, Thody AJ, Kerr DN, et al. Plasma immunoreactive beta melanocyte stimulating hormone and skin pigmentation in chronic renal failure. $\mathrm{Br}$ Med J 1975;1:658-9. https://doi.org/10.1136/ bmj.1.5959.658

12. Raiesifar Z, Tahery N, Shirzadegan R, Baraz S, Darabiyan P, Raiesifar A. Assessment of Skin Manifestations in End-Stage Renal Disease Patients Undergoing Hemodialysis in Shahid Beheshti Hospital of Abadan and Vali-eAsr Hospital of Khorramshahr. J Chronic Dis Care 2019;8:23-9. https://doi.org/10.5812/ jjcdc. 83381

13. Kolla PK, Desai M, Pathapati R, Valli VM, Pentyala S, Reddy GM. Cutaneous manifestations in patients with chronic kidney disease on maintenance hemodialysis. ISRN Dermatology 2012;2012:679619. https://doi. org/10.5402/2012/679619

14. Ashok VG, Mookambika RV, Murugan S. A study on dermatological manifestations among chronic kidney disease patients undergoing hemodialysis in a tertiary care centre. Int J Res Med Sci 2017;5:1814-7. https://doi.org/10.18203/23206012.ijrms20171582

15. Aqil N, Nassiri A, Gallouj S, Mernissi FZ. Nail Disorders in Patients with Chronic Renal Failure. J Dermatol Res Ther 2019;5:1-7. https://doi. org/10.23937/2469-5750/1510065

16. Saray $Y$, Seckin D, Gulec AT, Akgun S, Haberal $M$. Nail disorders in hemodialyses patients and renal transplant recipients: A case control study. J Am Acad Dermatol 2004;50:197-202. https:// doi.org/10.1016/j.jaad.2003.07.014

17. Thomas EA, Pawar B, Thomas A. A prospective study of cutaneous abnormalities in patients with chronic kidney disease. Indian J Nephrol 2012;22:116-20. https://doi.org/10.4103/09714065.97127

18. Anderson CK. Asteatotic eczema. E Med J 2002;538.

19. Park TH, Park $\mathrm{CH}, \mathrm{Ha} \mathrm{SK}$, Lee $\mathrm{SH}$, Song KS, Lee HY. Dry skin (xerosis) in patients undergoing 
maintenance haemodialysis: The role of decreased sweating of the eccrine sweat gland. Nephrol Dial Transplant 1995;10:2269-73. https://doi.org/10.1093/ndt/10.12.2269

20. Knable AL. Cutaneous nephrology. Dermatol Clin 2002;20:513-21. https://doi.org/10.1016/ S0733-8635(02)00012-8

21. Pisoni RL, Wikström B, Elder SJ, Akizawa T, AsanoY, Keen ML, et al. Pruritus in haemodialysis patients: International results from the Dialysis Outcomes and Practice Patterns Study (DOPPS) Nephrol Dial Transplant 2006;21:3495-505. https://doi.org/10.1093/ndt/gfl461

22. Kiliç Akça N, Taşci S. An important problem among hemodialysis patients: uremic pruritus and affecting factors. Turk Neph Dial Transpl 2014;23:210-16. https://doi.org/10.5262/ tndt.2014.1003.06
23. Leena JA, Noman MU, Islam MMSU, Ahmed AS, Ahmed DS, Rahman MM. Cutaneous Manifestations of Chronic Kidney Disease-An Observational Study in 100 Cases. Faridpur Med Coll J 2012;7: 33-6. https:// doi.org/10.3329/fmcj.v7i1.10296

24. Morton CA, Lafferty M, Hau C, Henderson I, Jones M, Lowe JG. Pruritis and skin hydration during dialysis. Nephron Dial Transplant 1996;11:20131-6. https:// doi.org/10.1093/oxfordjournals.ndt.a027092

25. Hajheydari Z, Makhlough A. Cutanenus and Mucosal manilestotion in patients on maintenance hemodialysis. Iran J Kidney Dis 2008;2:86-9.

26. Yaghubi R, Niloufar S. Latifee SM. Cutaneous manifestation of end stage Renal disease under hemodialysis. Iran J Dermatol 2002;5:29-34. 